\title{
Defining the Prevalence of Molar Incisor Hypomineralization in Brazil
}

\author{
Fernanda Mafei Félix da Silva ${ }^{1}$ D, Yuqiao Zhou$^{2}$ D , Fernanda Gabriela de Fátima Vieira1(D, Flávia
} Martinez de Carvalho ${ }^{3,4}\left(\mathbb{D}\right.$, Marcelo de Castro Costa $^{1}$ D, Alexandre Rezende Vieira ${ }^{2}$ (D)

\begin{abstract}
${ }^{1}$ Department of Paediatric Dentistry and Orthodontics, School of Dentistry, Federal University of Rio de Janeiro, Rio de Janeiro, RJ, Brazil.

2Department of Oral Biology, School of Dental Medicine, University of Pittsburgh, Pittsburgh, USA.

${ }^{3}$ Laboratory of Congenital Malformation Epidemiology, Oswaldo Cruz Institute, Rio de Janeiro, RJ, Brazil.

${ }^{4}$ Latin American Collaborative Study of Congenital Malformations, National Institute of Population Medical Genetics, Rio de Janeiro, RJ, Brazil.
\end{abstract}

Author to whom correspondence should be addressed: Alexandre Rezende Vieira, University of Pittsburgh, 335 Sutherland Dr. Pittsburgh, PA, USA. 15261. Phone: +1 412 383-8972. E-mail: alexandre_vieira@pitt.edu.

Academic Editors: Alessandro Leite Cavalcanti and Wilton Wilney Nascimento Padilha

Received: 21 August 2019 / Accepted: 13 November 2019 / Published: 25 November 2019

How to cite this article: Silva FMF, Zhou Y, Vieira FGF, Carvalho FM, Costa MC, Vieira AR. Defining the prevalence of
molar incisor hypomineralization in Brazil. Pesqui Bras Odontopediatria Clín Integr. 2020; $20: e 5146$.
https://doi.org/10.1590/pboci.2020.021
https://doi.org/10.1590/pboci.2020.021

\begin{abstract}
Objective: To define the prevalence of Molar Incisor Hypomineralization (MIH) in Brazil since the reports ranged from 2.5\% to $40.2 \%$. Material and Methods: We studied 407 children from 7 to 14 years of age. MIH was measured using the European Academy of Paediatric Dentistry criteria of 2003. Clinical data were collected by a calibrated dentist (Kappa $=0.88$ ) and included affected teeth and degree of MIH severity (mild/severe). Mild MIH cases were considered when the tooth presented demarcated opacity $\geq 1.0 \mathrm{~mm}$, without any loss of structure. While severe cases were defined by teeth in which loss of structure was present, or past or current lesion that required treatment, or presence of atypical restorations. In addition, published data (nine studies) reporting MIH in Brazilians were identified, and the heterogeneity of these studies was tested (I2 index/ p $\leq 0.01$ ). Results: In the original sample studied, the majority of patients were males $(55.3 \% ; \mathrm{n}=225)$, with an average age of 10.1 years $( \pm 2.1$ years $)$. The prevalence of MIH in this group was $14.5 \%$ (59 affected in 407), and most of the affected teeth had a mild degree of alteration (77.4\% or 202 in 261 teeth). Conclusion: A meta-analysis including nine published reports, and our original data showed that MIH prevalence in Brazil is 13.48 (95\% CI, 8.66\%-18.31\%).
\end{abstract}

Keywords: Dental Enamel Hypoplasia; Molar; Prevalence; Cross-Sectional Studies. 


\section{Introduction}

Molar Incisor Hypomineralization (MIH) is defined as a qualitative enamel defect that occurs during different stages of amelogenesis [1]. This condition usually affects at least one of the first permanent molars and may be associated with permanent incisors [2]. However, some studies report the association of MIH with permanent canines and primary second molars [3,4].

Disturbances during pregnancy, severe infections, the frequent use of antibiotics in childhood [5], and other exposures [6] have been investigated as etiologic factors and the genetics play role [7]. One of the main characteristics of MIH is enamel porosity and opacity, which may vary from white/yellowish to brown [2]. In some cases, MIH may cause the loss of tooth structure, resulting in functional (pain, tooth sensitivity and dental caries), and aesthetic problems for the individual [8].

It is suggested that the diagnosis of MIH should be performed on clean and wet teeth, and epidemiological studies of MIH should be based on 8-year-olds since, at this age, all permanent molars and incisors have erupted [2,9]. Likely due to different criteria of diagnosis, the prevalence of MIH varies considerably in different parts of the world ranging from 2.4 to 37\% in European countries [10-12], 2.5\% in China [13], and 2.5\% to 40\% [14-17] across Brazil. Due to these facts, the present study aimed to define the prevalence of MIH in Brazilians, which shows the widest range reported in the literature.

\section{Material and Methods}

Sample and Calibration

A sample consisting of 407 individuals of both sexes from 7 to 14 years of age treated at the Paediatric Dentistry. The inclusion criteria for this study was the patients having all first permanent molars erupted. Children with syndromes known to affect the enamel development were not included in the study.

To assess the intra-examiner reliability, an exercise was first applied to the examiner (F.M.F.S) and the gold standard evaluator (M.C.C.). Twenty clinical pictures of dental enamel defects (eight with MIH) were shown to the two individuals. Two weeks after the first assessment, a new assessment was carried out with the examiner, and the resulting Kappa was 0.88 .

\section{Clinical Examination}

The clinical examination was performed by the calibrated dentist (F.M.F.S) carried out with a mirror and a probe in the dental chair using artificial light. MIH was evaluated using the European Academy of Paediatric Dentistry (EAPD) [2,9]. Mild MIH cases were considered when the tooth presented demarcated opacity $\geq 1.0 \mathrm{~mm}$, without any loss of structure. While severe cases were defined by teeth in which loss of structure was present, or past or current lesion that required treatment, or presence of atypical restorations [2]. The study included 225 males (55.3\%) and 182 (44.7\%) females, with an average age of 10 years.

\section{Bibliographic Sources}

A database search was performed in PubMed, Lilacs (Latin American and Caribbean Health Sciences Literature) and BBO (Brazilian Bibliography of Dentistry) using the following terms: "Dental Enamel Hypoplasia”, "Molar Incisor Hypomineralization”, “MIH”, Hypomineralization Molar Incisor", "First permanent molars and incisors", "Prevalence", "Epidemiology", "Epidemiol" and "Brazil". A total of 383 references were identified and after excluding the publications that did not report denominators to allow calculation of frequencies, case reports, and studies that included the same sample of other publications, nine articles were selected (Table 1). 
Table 1. Characteristics of the articles (MIH study location, prevalence, and diagnostic criteria).

\begin{tabular}{|c|c|c|c|c|c|c|c|}
\hline $\begin{array}{l}\text { Author and } \\
\text { Year }\end{array}$ & City (State) & Type of Study & Sample & Age/Years & Calibration/Kappa & $\begin{array}{c}\text { Prevalence } \\
\text { MIH\% }\end{array}$ & $\begin{array}{l}\text { Diagnostic } \\
\text { Criteria }\end{array}$ \\
\hline $\begin{array}{l}\text { Soviero et al., } \\
2009[17]\end{array}$ & $\begin{array}{l}\text { Rio de Janeiro } \\
\qquad(\mathrm{RJ})\end{array}$ & Cross-Sectional & 249 & $7-13$ & $\begin{array}{c}\text { 0.80/0.90/0.96 } \\
\text { Theoretical + Clinical Examination }\end{array}$ & 40.2 & $\begin{array}{l}\text { EAPD (2003) } \\
\text { Koch (2001) } \\
\text { Opacity (-----) }\end{array}$ \\
\hline $\begin{array}{l}\text { Costa Silva et al., } \\
2010[8]\end{array}$ & Botelhos (MG) & Cross-Sectional & 918 & $6-12$ & $\begin{array}{c}0.91 \\
\text { Photographs }\end{array}$ & 19.8 & $\begin{array}{l}\operatorname{EAPD}(2003) \\
\text { Opacity }>1.0 \mathrm{~mm}\end{array}$ \\
\hline $\begin{array}{l}\text { Jeremias et al., } \\
\quad 2013[7]\end{array}$ & Araraquara (SP) & Cross-Sectional & 1.157 & $6-12$ & 0.91 & 12.3 & $\begin{array}{l}\operatorname{EAPD}(2003) \\
\text { Opacity }>2.0 \mathrm{~mm}\end{array}$ \\
\hline $\begin{array}{l}\text { Hanan et al., } \\
2015[18]\end{array}$ & Manus (AM) & Cross-Sectional & 2.062 & $6-10$ & $\begin{array}{l}\text { O.87 } \\
\text { Clinical Examination }\end{array}$ & 9.12 & $\begin{array}{l}\text { EAPD (2003) } \\
\text { Opacity }>2.0 \mathrm{~mm}\end{array}$ \\
\hline $\begin{array}{l}\text { Rodrigues et al., } \\
\quad 2015[19]\end{array}$ & São Luis (MA) & Cross-Sectional & 1.179 & $7-14$ & $\begin{array}{c}0.91 \\
\text { Photographs }\end{array}$ & 2.5 & $\begin{array}{l}\text { EAPD }(2003) \\
\text { Opacity }>2.0 m m\end{array}$ \\
\hline $\begin{array}{l}\text { Silva Junior et al., } \\
\qquad 2015[14]\end{array}$ & Belém (PA) & Cross-Sectional & 260 & $5-17$ & $\begin{array}{l}0.7 \\
\text { Clinical Examination }\end{array}$ & 8.84 & $\begin{array}{l}\text { EAPD (2003) } \\
\text { Opacity }>2.0 \mathrm{~mm}\end{array}$ \\
\hline $\begin{array}{c}\text { Lima et al., } 2016 \\
{[20]}\end{array}$ & Teresina (PI) & Cross-Sectional & 594 & $11-14$ & $\begin{array}{c}0.91 \\
\text { Theoretical }+ \text { Clinical Examination }\end{array}$ & 18.4 & $\begin{array}{l}\text { EADP }(2003) \\
\text { Opacity }>1.0 \mathrm{~mm}\end{array}$ \\
\hline $\begin{array}{l}\text { Tourino et al., } \\
2016[21]\end{array}$ & Lavras (MG) & Cross-Sectional & 1.181 & $8-9$ & $\begin{array}{c}0.96 \\
\text { Theoretical }+ \text { Photographs }+ \\
\text { Clinical examination }\end{array}$ & 20.4 & $\begin{array}{l}\text { EADP }(2003) \\
\text { Opacity }>1.0 \mathrm{~mm}\end{array}$ \\
\hline $\begin{array}{l}\text { Costa Silva et al., } \\
2017[16]\end{array}$ & Botelhos (MG) & $\begin{array}{l}\text { Prospective } \\
\text { Cohort }\end{array}$ & 142 & $5-6$ & $\begin{array}{c}0.93 \\
\text { Theoretical }+ \text { Photographs }\end{array}$ & 16.1 & $\begin{array}{l}\text { EADP }(2003) \\
\text { Opacity }>1.0 \mathrm{~mm}\end{array}$ \\
\hline
\end{tabular}


Statistical Analysis

Data were analyzed using SPSS version 20.0 (Statistical Package for Social Sciences, SPSS Inc., Chicago, III). Chi-square, with a significance level set at 5\%, was used to compare the MIH distribution by sex. The prevalence estimates from the literature were pooled together using random-effects meta-analysis that accounted for between-study heterogeneity. Statistical heterogeneity (RevMan) was assessed by the chi-square test on $\mathrm{Q}$ statistic, which was quantified by the I-square values. I-square values of 25,50 , and $75 \%$ were nominally assigned as low, moderate, and high estimates, respectively.

Ethical Aspects

This study was performed after approval from the local Ethics Committee for Research Hospital Universitário Clementino Fraga Filho (Protocol No. 44598514.7.00005257). All subjects/guardians read and signed a written informed consent before their participation in the study.

\section{Results}

The prevalence of $\mathrm{MIH}$ in the studied sample was $14.5 \%$ (59 affected in 407 individuals studied), and there was no statistically significant difference in MIH affection by sex $(\mathrm{p}=0.914)$.

A total of 261 teeth were affected by MIH, 33\% of them $(n=86)$ were first permanent maxillary molars, 28.3\% $(\mathrm{n}=74)$ first permanent mandibular molars, 22.2\% $(\mathrm{n}=58)$ permanent maxillary incisors, and $16.5 \%(\mathrm{n}=43)$ permanent mandibular incisors. According to the degree of severity, it was observed that most teeth were mildly affected by MIH (77.4\%; 202 in 261 affected teeth). Among the most severely affected teeth, most of them were first permanent molars (84.7\%; 50 in 160 affected molars) (Table 2$)$.

Table 2. Characteristics of the MIH group.

\begin{tabular}{lcc}
\multicolumn{1}{c}{ Variables } & MIH Group (n=59) \\
\hline Mean Age (SD) & \multicolumn{2}{c}{$10.15( \pm 1.5)$} \\
Sex & \multicolumn{2}{c}{$\mathrm{N}(\%)$} \\
$\quad$ Male & \multicolumn{2}{c}{$33(55.9)$} \\
Female & \multicolumn{2}{c}{$26(41.1)$} \\
Teeth Affected by MIH & Mild & Severe \\
& $\mathrm{N}(\%)$ & $\mathrm{N}(\%)$ \\
Permanent Maxillary Central Incisors & $38(18.1)$ & $6(10.2)$ \\
Permanent Maxillary Lateral Incisors & $13(6.4)$ & $1(1.6)$ \\
Permanent Mandibular Central Incisors & $26(13)$ & $1(1.6)$ \\
Permanent Mandibular Lateral Incisors & $15(7.5)$ & $1(1.6)$ \\
Firs Permanent Maxillary Molars & $64(32)$. & $22(37.4)$ \\
First Permanent Mandibular Molars & $46(23)$. & $28(47.6)$ \\
\multicolumn{1}{c}{ Total } & $202(77.4)$ & $59(22.6)$ \\
\hline
\end{tabular}

Meta-analysis was performed on data from nine articles results in addition to our original data. Figure 1 shows the estimates of MIH reported by the ten studies, which yielded a summary prevalence of $15.92(95 \%$ CI, $10.85 \%-21.00 \%)$ with significant evidence of between study heterogeneity $(Q=521.81, \mathrm{p}<0.01, \mathrm{I} 2=98)$ (Figure 1). In an attempt to reduce heterogeneity, the sensitivity analysis was performed by removing the study that reported a different clinical diagnostic (the size of the lesions was not taken into consideration and used two methods for diagnostics). The new estimate was 13.48 (95\% CI, 8.66\%-18.31\%) (Figure 2). 


\section{Study}

Soviero et al.2009

Da Costa Silva et al.2010

Jeremias et al.2013

Moura et al.2015

Hanan et al.2015

Nogueira Rodrigues et al.2015

If Jr et al. 2015

Tourino et al.2016

Da Costa Silva et al.2017

*This Study

\section{Random effects model}

Heterogeneity: $I^{2}=98 \%, \chi_{9}^{2}=521.81(p<0.01)$

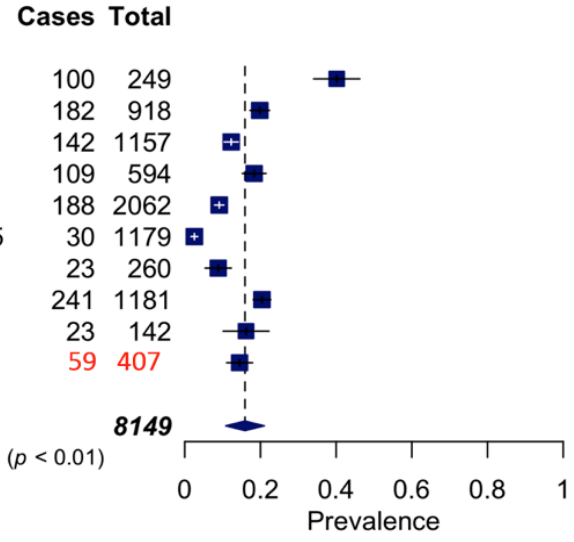

95\% C.I. Weights

$0.4016[0.3407 ; 0.4625] \quad 9.1 \%$

$0.1983[0.1725 ; 0.2240] \quad 10.2 \%$

$0.1227[0.1038 ; 0.1416] \quad 10.3 \%$

$0.1835[0.1524 ; 0.2146] \quad 10.1 \%$

$0.0912[0.0787 ; 0.1036] \quad 10.4 \%$

$0.0254[0.0165 ; 0.0344] \quad 10.4 \%$

$0.0885[0.0539 ; 0.1230] \quad 10.0 \%$

$0.2041[0.1811 ; 0.2270] \quad 10.3 \%$

$0.1620[0.1014 ; 0.2226] \quad 9.1 \%$

$0.1450[0.1108 ; 0.1792] \quad 10.0 \%$

$0.1592[0.1085 ; 0.2100] 100.0 \%$

*The new prevalence study of MIH.

Figure 1. Plot MIH of prevalence with a new result.

\section{Study}

Da Costa Silva et al.2010

Jeremias et al.2013

Moura et al.2015

Hanan et al.2015

Nogueira Rodrigues et al.2015

If $\mathrm{Jr}$ et al.2015

Tourino et al.2016

Da Costa Silva et al.2017

*This Study

Random effects model

Heterogeneity: $I^{2}=98 \%, \chi_{8}^{2}=418.50(p<0.01)$
Cases Total

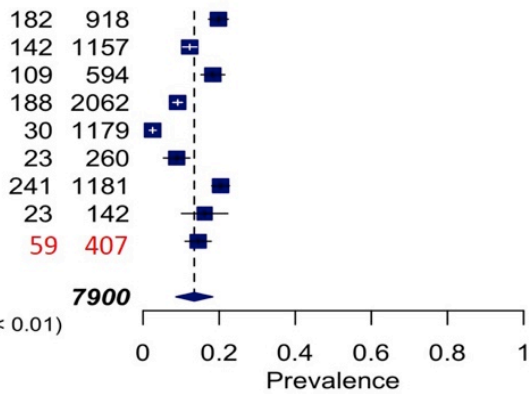

\section{Proportion \\ 95\% C.I. Weights}

$0.1983[0.1725 ; 0.2240] \quad 11.3 \%$

$0.1227[0.1038 ; 0.1416] \quad 11.4 \%$

$0.1835[0.1524 ; 0.2146] \quad 11.1 \%$

$0.0912[0.0787 ; 0.1036] \quad 11.5 \%$

$0.0254[0.0165 ; 0.0344] \quad 11.6 \%$

$0.0885[0.0539 ; 0.1230] \quad 11.0 \%$

$0.2041[0.1811 ; 0.2270] \quad 11.3 \%$

$0.1620[0.1014 ; 0.2226] \quad 9.8 \%$

$0.1450[0.1108 ; 0.1792] \quad 11.0 \%$

$0.1348[0.0866 ; 0.1831] 100.0 \%$

*The new prevalence study of MIH.

Figure 2. Plot MIH of prevalence without Soviero et al. [17].

\section{Discussion}

There is great interest in understanding why MIH occurs, but this is a difficult task if we do not have even a decent estimate of the prevalence of the condition. However, it is notable that over the years, prevalence studies of MIH have been increasing mainly in Brazil.

The prevalence of MIH in the present study was 14.5\%, which was consistent with most of the literature [22,23]. Not surprising, the prevalence estimate in our sample is close to the one found in the city of São Paulo (12.3\%) [15], which is just 400 kilometers from downtown Rio de Janeiro. This may also be due to the diagnostic criteria that was similar among these studies. The frequency in the north-eastern region of Brazil appears to be lower $[18,14]$. This may be due to the inclusion of opacities greater than 2 mm in studies conducted in the region, which makes it more a strict criterion.

The meta-analysis showed high heterogeneity among the studies included. This is probably related to the use of different indexes, diagnostic criteria, and age groups. All selected articles had their examiners calibrated, but in different types of photographic training, clinical examination, or both. Eight studies, included our original data, used the same diagnostic criteria. Some studies included in the meta-analysis [14,19,20], 
except for one [16], reported lower prevalence compared to our study, probably because they considered only opacities that were larger than 2 millimeters of diameter.

In our sample, most cases had mild $\mathrm{MIH}$, although more than $50 \%$ of affected teeth were first permanent molars with some degree of loss of structure. Such cases can have discomfort, caries lesion development, and esthetic concerns [14]. Prevalence studies are important to help formulate strategies to prevent or reduce the possibility of the consequences of MIH.

\section{Conclusion}

The prevalence of MIH in Brazilians is 13.48 (95\% CI, $8.66 \%-18.31 \%$ ).

\section{Authors' Contributions}

\begin{tabular}{|c|c|c|c|c|}
\hline FMFS & (iD) $0000-0003-3247-7746$ & $\begin{array}{l}\text { Conceptualization, Methodology, Investigation, Writing - } \\
\text { Preparation and Writing - Review and Editing. }\end{array}$ & - Original & Draft \\
\hline YZ & (iD) $0000-0001-9450-4055$ & Validation, Formal Analysis and Writing - Review and Editing. & & \\
\hline FGFV & (D) $0000-0001-9437-1715$ & Investigation and Writing - Review and Editing. & & \\
\hline FMC & (iD) 0000-0003-2617-9689 & Formal Analysis and Writing - Review and Editing. & & \\
\hline $\mathrm{MCC}$ & (iD) $0000-0003-2192-1960$ & Formal Analysis and Writing - Review and Editing. & & \\
\hline ARV & (iD) $0000-0003-3392-6881$ & $\begin{array}{l}\text { Conceptualization, Methodology, Formal Analysis, Writing } \\
\text { Preparation and Writing - Review and Editing. }\end{array}$ & - Original & Draft \\
\hline
\end{tabular}

\section{Financial Support}

This study was financed in part by the Coordenação de Aperfeiçonamento de Pessoal de Nivel Superior Brasil - (CAPES) Finance Code 001.

\section{Conflict of Interest}

The authors declare no conflicts of interest.

\section{References}

[1] Seow WK. Clinical diagnosis of enamel defects: pitfalls and practical guidelines. Int Dent J 1997; 47(3):173-82. https://doi.org/10.1002/j.1875-595x.1997.tbo0783.x

[2] Lygidakis NA, Wong F, Jälevik B, Vierrou AM, Alaluusua S, Espelid I. Best clinical practice guidance for clinicians dealing with children presenting with Molar-Incisor-Hypomineralisation (MIH): an EAPD policy document. Eur Arch Paediatr Dent 2010; 11(2):75-81. https://doi.org/10.1007/bfo3262716

[3] Elfrink ME, ten Cate JM, Jaddoe VW, Hofman A, Moll HA, Veerkamp JS. Deciduous molar hypomineralization and molar incisor hypomineralization. J Dent Res 2012; 91(6):551-5. https://doi.org/10.1177/0022034512440450

[4] Schmalfuss A, Stenhagen KR, Tveit AB, Crossner CG, Espelid I. Canines are affected in 16-year-olds with molarincisor hypomineralisation (MIH): an epidemiological study based on the Tromsø study: "fit futures". Eur Arch Paediatr Dent 2016; 17(2):107-13. https://doi.org/10.1007/s40368-015-0216-6

[5] Alaluusua S. Aetilogy of molar-incisor hypomineralization: a systematic review. Eur Arch Paediatr Dent 2010; 11(2):53-8. https://doi.org/10.1007/bfo3262713

[6] Vom Saal FS, Nagel SC, Coe BL, Angle BM, Taylor JA. The estrogenic endocrine disrupting chemical bisphenol A (BPA) and obesity. Mol Cell Endocrinol 2012; 354 (1-2):74-84. https://doi.org/10.1016/j.mce.2012.01.001

[7] Jeremias F, Pierri RA, Souza JF, Fragelli CM, Restrepo M, Finoti LS, et al. Family-based genetic association for molar-incisor hypomineralization. Caries Res 2016; 50 (3):310-8. https://doi.org/10.1159/000445726

[8] Costa-Silva CM, Jeremias F, de Souza JF, Cordeiro RC, Santos-Pinto L, Zuanon AC. Molar incisor hypomineralization: prevalence, severity and clinical consequences in Brazilian children. Int J Paediatr Dent 2010; 20(6):426-34. https//doi.org/10.1111/j.1365-263X.2010.01097.x

[9] Weerheieijm KL, Duggal M. Majáre I, Papagiannoulis L, Koch G, Martens LC, et al. Judgement criteria for molar incisor hypomineralisation (MIH) in epidemiologic studies: a summary of the European meeting on MIH held in Athens, 2003. Eur J Paediatr Dent 2003; 4 (3):110-3. 
[10] Kukleva MP, Petrova SG, Kondeva VK, Nihtyanova TI. Molar incisor hypomineralisation in 7-to-14-year old children in Plovdiv, Bulgaria - an epidemiologic study. Folia Med 2008; 50(3):71-5.

[11] Dietrich G, Sperling S, Hetzer G. Molar incisor hypomineralisation in a group of children and adolescents living in Dresden (Germany). Eur J Paediatr Dent 2003; 4(3):133-7.

[12] Wogelius P, Haubek D, Poulsen S. Prevalence and distribution of demarcated opacities in permanent 1st molars and incisors in 6 to 8-year-old Danish children. Acta Odontol Scand 2008; 66(1):58-64. https://doi.org/10.1080/00016350801926941

[13] Cho S, Ki Y, Chu V. Molar incisor hypomineralization in Hong Kong Chinese children. Int J Paediatr Dent 2008; 18(5):348-52. https://doi.org/10.1111/j.1365-263X.2008.00927.x

[14] Silva Júnior IF, Aguiar NL, Barros WRC, Silva LS, Arantes DC, Nascimento LS. Prevalence and severity of molar incisor hypomineralization in students of Belém, Brazil. Pesqui Bras Odontopediatria Clin Integr 2015; 15(1):377-85. https://doi.org/10.4034/PBOCI.2015.151.40

[15] Jeremias F, Souza JF, Silva CM, Cordeiro RC, Zuanon AC, Santos-Pinto L. Dental caries experience and molarincisor hypomineralization. Acta Odontol Scand 2013; $71(3-4): 870-6$. https://doi.org/10.3109/00016357.2012.734412

[16] Costa Silva CM, Ortega EMM, Mialhe FL. The impact of molar-incisor hypomineralisation on dental caries in permanent first molars: a prospective cohort study. Oral Health Prev Dent 2017; 15(6):581-6. https://doi.org/10.3290/j.ohpd.a39590

[17] Soviero V, Haubek D, Trindade C, Matta T, Poulsen S. Prevalence and distribution of demarcated opacities and their sequelae in permanent 1st molars and incisors in 7 to 13-year-old Brazilian children. Acta Odontol Scand 2009; 67(3):170-5. https://doi.org/10.1080/00016350902758607

[18] Hanan SA, Alves Filho AO, Medina PO, Cordeiro RCL, Santos-Pinto L, Zuanon ACC. Molar-incisor hypomineralization in schoolchildren of Manaus, Brazil. Pesqui Bras Odontopediatria Clin Integr 2015; 15(1):309-17. https://doi.org/10.4034/PBOCI.2015.151.33

[19] Rodrigues FCN, Ribeiro PHB, Thomaz EBAF, Lima GQT, Neves PAM, Ribeiro CCC. Molar-incisor hypomineralization in schoolchildren of São Luis, Brazil, Maranhão: Prevalence and associated factors. Pesqui Bras Odontopediatria Clin Integr 2015; 15(1):271-8 https://doi.org/10.4034/PBOCI.2015.151.29

[20] Lima MD, Andrade MJ, Dantas-Neta NB, Andrade NS, Teixeira RJ, Moura MS, et al. epidemiologic study of molarincisor hypomineralization in schoolchildren in north-eastern Brazil. Pediatr Dent 2015; 37(7):513-9.

[21] Tourino LF, Correa-Faria P, Ferreira RC, Bendo CB, Zarzar PM, Vale MP. Association between molar incisor hypomineralization in schoolchildren and both prenatal and postnatal factors: a population-based study. PLoS One 2016; 11(6):e0156332. https://doi.org/10.1371/journal.pone.015633

[22] Zawaideh FI, Al-Jundi SH, Al-Jaljoli MH. Molar incisor hypomineralisation: prevalence in Jordanian children and clinical characteristics. Eur Arch Paediatr Dent 2011; 12(1):31-6. https://doi.org/10.1007/bfo3262776

[23] Kuscu O, Caglar E, Aslan S, Durmusoglu E, Karademir A, Sandalli N. The prevalence of molar incisor hypomineralization $(\mathrm{MIH})$ in a group of children in a highly polluted urban region and a windfarm-green energy island. Int J Paediatr Dent 2009; 19(3):176-85. https://doi.org/10.1111/j.1365-263X.2008.00945.x 